Z. klin. Chem. u. klin. Biochem.

8. Jg., S. 557-563, November 1970

\title{
New Colorimetric Micromethod for the Estimation of $\gamma$-Glutamyl Transpeptidase Activity in Biological Samples
}

\author{
By J. SwinNen \\ From the Department of Clinical Chemistry, Institute Bunge, Bercbem (Antwerp), Bclgium
}

(Eingegangen am 19. Mai 1970)

\begin{abstract}
A new colorimetric micromethod for the estimation of $\gamma$-glutamyl transpeptidase activity has been developed, in order to obtain more reliable results with greater ease on smaller samples of a wider variety. Enzyme activity can be determined on $0.1 \mathrm{~m} /$ of serum or less, or the equivalent of spinal fluid or tissue extracts, because the precipitation of proteins has been omitted.

Therefore, correction for possible losses of the reaction product, $\alpha$-naphthylaminc, is no longer necessary and the chromogen can be diluted without the risk of turbidity, thus permitting the estimation of very low, as well very high enzyme activities. The method utilizes 2 different substrates, designed to determine peptidase and transpeptidase activity, respectively, the differentiation of which is of empirical significance.

The clinical results suggests that $\gamma$-glutamyl transpeptidase is a common name for a group of cnzymes, some of which occur in an insoluble microsomal form, others in a soluble form. There is good cvidence that the increased activation by glycylglycine is the result of an increased conversion of the microsomal enzyme to the soluble form and that the transpeptidation activity increases more readily than the peptidase.
\end{abstract}

Es wurde eine neue kolorimetrische Mikromethode zur Bestimmung von $\gamma$-Glutamyltranspeptidase entwickelt, um zuverlässigere Ergebnisse an kleineren Proben verschiedenster Herkunft einfacher zu erhalten. Die Enzymaktivität kann in $0,1 \mathrm{ml}$ oder weniger Serum bzw. der analogen Menge Liquor cerebrospinalis oder Gewebsextrakt bestimmt werden, wobei die Proteinfällung weggelassen wurde. Aus diesen Grunden ist eine Korrektur für mögliche Verluste des Reaktionsproduktes $\alpha$-Naphthylamin nicht mehr erforderlich; das Chromogen kann ohne Gefahr der Trübung verdünnt werden, was die Bestimmung sehr geringer als auch sehr hoher Enzymaktivitäten gestattet. Die Methode benutzt zwei Substrate, um Peptidase- und Transpeptidase-Aktivität zu bestimmen, deren Differenzierung erfahrungsgemäß von Bedeutung ist.

Die klinischen Ergebnisse weisen darauf hin, daß $\gamma$-Glutamyltranspeptidase ein gemeinsamer Name für eine Gruppe von Enzymen ist, die teils in einer unlöslichen, mikrosomalen Form, teils in löslicher Form vorliegen. Es gibt gute Beweise dafür, daß die zunehmende Aktivierung durch Glycylglycin das Ergebnis einer zunehmenden Umwandlung des mikrosomalen Enzyms in die lösliche Form ist und daß die Transpeptidaseaktivität eher ansteigt als die der Peptidase.

The biological significance of $\gamma$-glutamyl transpeptidase is not known; it may play an important role in protein synthesis (1). The enzyme belongs to the exopeptidases that cleave the terminal peptide bond, provided that the glutamyl moiety has a free carboxyl group. In other words, the enzyme is a carboxy-peptidase. It has not yet been isolated, despite several attempts $(2,3,18)$. As pointed out by GolDbarg and coworkers (4) the terminal glutamyl residue is transferred to suitable acceptors, particularly peptides but also to L-amino acids, and even water has been found to act as an acceptor. Accordingly, one can distinguish three different types of reactions catalysed by $\gamma$-glutamyl transpeptidase:

1. Hydrolysis or $\gamma$-glutamyl peptidase activity. In this reaction the terminal glutamyl residue is split off hydrolytically as free glutamic acid (6). The remainder of the molecule may represent either a peptide, an amino acid or an amine, the latter being the case with the present method.

2. Internal transpeptidation. The liberated glutamyl residue can be transferred to the substrate (5-9), forming a $\gamma$-glutamyl- $\gamma$-glutamyl peptide. Since the present method uses $\gamma$-glutamyl- $\alpha$-naphthylamide as the in vitro substrate, "internal transpeptidation" results in $\gamma$ glutamyl- $\gamma$-glutamyl- $\alpha$-naphthylamide.
Amino acid paper chromatography of the reaction products has conclusively demonstrated internal transpeptidation to represent a significant part of the enzymic reaction (17). However, the colorimetric method described here will, of course, not differentiate between hydrolysis and internal transpeptidation.

3. External transpeptidation. In the presence of certain L-amino acids and several di- and tripeptides, the enzymic hydrolysis of the terminal glutamyl residue is coupled with its transfer to L-amino acids or peptides which act as acceptors (11). This transpeptidation results in the formation of new $\gamma$-glutamyl peptides. Using paper chromatography we could demonstrate that $\gamma$-glutamyl- $\alpha$-naphthylamide also acts as an acceptor though to a much lesser degree than glycylglycine, which is unanimously considered to be the most avid acceptor for the $\gamma$-glutamyl moiety.

Using paper chromatography it can be demonstrated that the three reactions occur simultaneously only in pancreas extract and in serum. Simple hydrolysis of the substrate actually occurs in the presence of high concentrations of glycylglycine in all the tissue extracts and tissue fluids studied.

External transpeptidation was observed in all tissue extracts or tissue fluids, except in kidney extracts, in which the glycylglycine was too readily hydro- 
lysed and the glycine itself did not act as an acceptor (17).

Our findings are ostensibly in contrast to those of GoldDarg and coworkers (4) who employed fresh rat kidney homogenates and those of SzEwCZur and BARANOWSKI (18) using purified beef kidney extract.

Thus far, the determination of $\gamma$-glutamyl transpeptidase activity has been particularly helpful in respect to the diagnosis of liver diseases (9) and SzczexiIK and coworkers (9) stated rather categorically that "A high serum $\gamma$-glutamyl transpeptidase activity, not associated with jaundice, is a finding very suggestive of a primary or metastatic liver cancer". In our experience $(15,16)$, the determination of the $\gamma$-glutamyl transpeptidase activity spans a much wider range of clinical applicability. It permits the differentiation of toxic from viral liver damage, and intra- or extrahepatic obstruction from functional liver insufficiency. In addition, preliminary studies indicate its diagnostic usefulness in muscle disorders and intestinal infections. These observations provided the stimulus to develop the present micromethod which enables the test to be performed in the averagie laboratory at a relatively minor expense.

\section{Methods}

The biological sample is incubated at $37^{\circ}$ in a buffered solution of $\gamma$-glutamyl- $\alpha$-naphthylamide for 1 to 24 hours, depending on the respective activity. The liberated $\alpha$-naphthylamine is diazotized directly and the concentration of the reaction product determined colorimetrically. The intensity of the colour is equivalent to the concentration of $\alpha$-naphthylamine and therefore to the enzymic activity. If no acceptor is added, the amount of hydrolysis and/or internal transpeptidation is measured, whereas if the substrate solution contains glycylglycine, the color change is predominantly due to transpeptidation, as shown by paper chromatography(17) Internal transpeptidation and hydrolysis will also occur with this substrate, though to a relatively small extent.

Reagents

1. Substrate for determination of bydrolytic activity

$\gamma$-glutamyl- $\alpha$-naphthylamide [prepared according the method of OrLOWSKI and SzEwCZUK (7)] $290 \mathrm{mg}$.

Tris-(hydroxymethyl)-aminomethane solution $0.1 \mathrm{M}$ in $\mathrm{H}_{2} \mathrm{O}: 50 \mathrm{ml}$. The $\gamma$-glutamyl- $\alpha$-nahpthylamide is dissolved in tris buffer by boiling and after cooling, water is added to make $90 \mathrm{~m} /$. The $\mathrm{pH}$ is then adjusted to 9.0 and more water added to make a volume of $100 \mathrm{~m} l$.

This solution can be stored for 14 days at $4^{\circ}$. It contains $10 \mu$ moles $\gamma$-glutamyl- $\alpha$-naphthylamide/ml.

2. Substrate for determination of transpeptidase activity

$\gamma$-glutamyl- $\alpha$-naphthylamide: $290 \mathrm{mg}$.

Tris-(hydroxymethyl)-aminomethane solution $0.1 \mathrm{M}$ in $\mathrm{H}_{2} \mathrm{O}: 50 \mathrm{ml}$. The solution is prepared as above but before the $\mathrm{pH}$ is adjusted to $9.0,100 \mathrm{mg}$ of glycylglycine are added. The substrate contains $10 \mu$ moles $\gamma$-glutamyl- $\alpha$-naphthylamide $/ \mathrm{m} l$ and $7.5 \mu$ moles glycylglycine $/ \mathrm{m} l$ and can also be stored for 2 weeks at $4^{\circ}$.

\section{Diazo reagent}

(A) $0.4 \%$ sulphanilic acid solution.

$0.4 \mathrm{~g}$ of sulphanilic acid is dissolved in $6 \mathrm{ml}$ of concentrated $\mathrm{HCl}$. Water is added to make $100 \mathrm{~m} /$. The solution is stable at room temperature.

(B) $1 \%$ sodium nitrite solution $\left(\mathrm{NaNO}_{2}\right.$ in water). This solution must be prepared at least once a week.

\section{(C) Working solution}

sulphanilic acid solution (A) $\quad 5.0 \mathrm{ml}$

sodium nitrite solution (B) $\quad 0.5 \mathrm{ml}$

distilled water

$14.5 \mathrm{ml}$

This reagent must be used within 30 minutes after preparation.

4. Dilution fluid

propylene glycol $10 \mathrm{ml}$

methanol p. A. $45 \mathrm{ml}$

distilled water $\quad 45 \mathrm{ml}$

May be stored indefinitely at room temperature.

5. Standard solution

(A) Stock solution $(20 \mu \mathrm{moles} / \mathrm{m} l)$

$288 \mathrm{mg} \alpha$-naphthylamine (1-amino-naphthalene) is dissolved in $100 \mathrm{ml}$ propylene glycol-water $(1: 1 ; \nabla / v)$.

(B) Working standard $(0.2 \mu \mathrm{moles} / \mathrm{m} l)$

The stock solution is diluted 1:100 with propylene glycol water $(1: 1 ; \nabla / v)$. The standard must be prepared freshly.

Method for serum

Place in four test tubes $(18 / 180 \mathrm{~mm})$

\begin{tabular}{lcccc}
\hline & blank (test) & test & blank(st) & standard \\
\hline substrate at $37^{\circ}$ & $0.5 \mathrm{~m} l$ & $0.5 \mathrm{~m} l$ & - & - \\
serum & - & $0.1 \mathrm{~m} l$ & - & - \\
incubate for 60 minutes at $37^{\circ}$ & & & \\
serum & $0.1 \mathrm{~m} l$ & - & - & - \\
water & - & - & $0.6 \mathrm{~m} l$ & $0.4 \mathrm{~m} l$ \\
working standard & - & - & - & $0.2 \mathrm{~m} l$ \\
diazo reagent & $1.0 \mathrm{~m} l$ & $1.0 \mathrm{~m} l$ & $1.0 \mathrm{~m} l$ & $1.0 \mathrm{~m} l$ \\
dilution fluid & $4.0 \mathrm{~m} l$ & $4.0 \mathrm{~m} l$ & $4.0 \mathrm{~m} l$ & $4.0 \mathrm{~m} l$ \\
\hline
\end{tabular}

Leave at room temperature for 10 minutes, protected from direct light. The extinction is measured at $535 \mathrm{~nm}$ and the activity expressed as $\mu$ moles $\alpha$-naphthylamine $/ 1000 \mathrm{~m} / / \mathrm{min}$ at $37^{\circ}$ in relation to the standard solution.

O.D.st $=\frac{0.04 \times 10,000}{60}=6.66 \mu \mathrm{moles} / 1000 \mathrm{~m} / / \mathrm{min}$ at $37^{\circ}$.

$0.04=\mu \mathrm{mol} \alpha$-naphthylamine in the standard solution.

$10,000=$ conversion factor for $0.1 \mathrm{~m} /$ to $1000 \mathrm{~m} /$.

$60=$ time conversion factor.

\section{Technical Results}

The method described here is inspired by the techniques of OrLowski and SzEwCżuK (7) and of GoldBARG and coworkers (11). The reaction proceeds at $37^{\circ}$, which is the optimal temperature for serum and cerebrospinal fluid (15). The activity is expressed in $\mu$ moles $/ 1000 \mathrm{~m} / / \mathrm{min}$ at $37^{\circ}$ in agreement with ORLOWSKI and SZEWCZUK (7).

Our improvements involve three different steps. The quantity of the sample is reduced from $0.25 \mathrm{~m} l$ to $0.1 \mathrm{~m} l$ (7). This became possible after ommission of the precipitation of protein followed by direct diazotation of the reaction product after GRIESS (12). The preceding changes eliminate the necessity to correct for possible losses of reaction product incurred by the precipitation of protein. The final step, the dilution of the reaction mixture after diazotation with the propylene glycol/ methanol/water, permits the determination of very high enzyme activities without risking turbidity of the 
reaction mixture. Therefore the technique can be applied to biological samples other than serum, for example tissue extracts or bacteriological cultures.

Several parameters of the technique have been systematically examined with the following results:

\section{A. Buffer}

According to Goldbarg and coworkers (4), hydrolysis of $\gamma$-glutamylanilide by rat kidney is highest in a phosphate buffer at $\mathrm{pH}$ 8.7. Nevertheless, these authors used a veronal buffer $(0.1 \mathrm{M} ; \mathrm{pH} 8.7)$ because spontaneous hydrolysis of the substrate is very high in phosphate. Enzymic activity at $\mathrm{pH} 8.7$ is about the same with borate and veronal buffers, but lower with

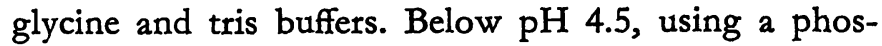
phate-citrate buffer and above $\mathrm{pH} 10.5$ employing a borate buffer, no enzymic activity was detectable (4). Transpeptidase activity in serum, using methionine as acceptor, was about $20 \%$ greater in tris buffer $(0.1 \mathrm{M}$; $\mathrm{pH}$ 8.7) than in veronal buffer of identical concentration and $\mathrm{pH}$ (11). Using glycylglycine and as buffer and as acceptor $(0.11 \mathrm{M})$, the serum $\gamma$-glutamyl transpeptidase activity was determined at $\mathrm{pH} 7.4(13,14)$.

In agreement with OrLowskI and SzewCzUK (7), we found a $\mathrm{pH}$ maximum of 9.0 for serum and cerebrospinal fluid, and the activity was highest with $0.05 \mathrm{M}$ tris buffer (fig. 1). Spontaneous hydrolysis of the substrate was greatest in phosphate buffer at $\mathrm{pH} 9.0$.

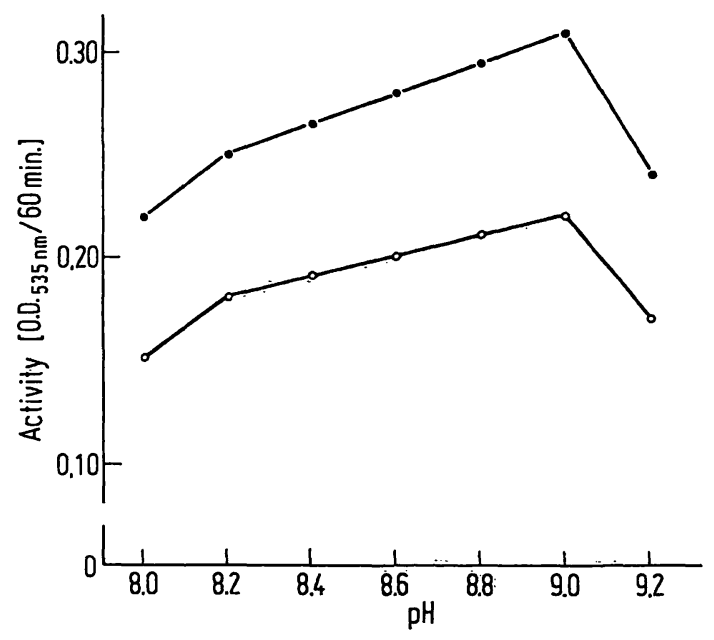

Fig. 1

Peptidase and internal transpeptidase $(\circ-0)$ and transpeptidase (๑activities in serum as a function of $\mathrm{pH}$ with $0.05 \mathrm{M}$ Tris buffer

\section{B. Stability of substrates}

At $4^{\circ}$, substrate solution 1 shows a $0.14 \%$ hydrolysis over a period of 14 days and the substrate 2, with the added glycylglycine, undergoes $0.28 \%$ hydrolysis. After 30 days of storage, hydrolysis increases to $0.40 \%$ and $0.54 \%$ respectively. Spontaneous hydrolysis is enhanced to $1.9 \%$ and $2.5 \%$ respectively after 14 days at $37^{\circ}$ (fig. 2).

Some bacteria contain a $\gamma$-glutamyl transferase-like enzyme and therefore bacterial contamination renders the substrate useless (results to be published).

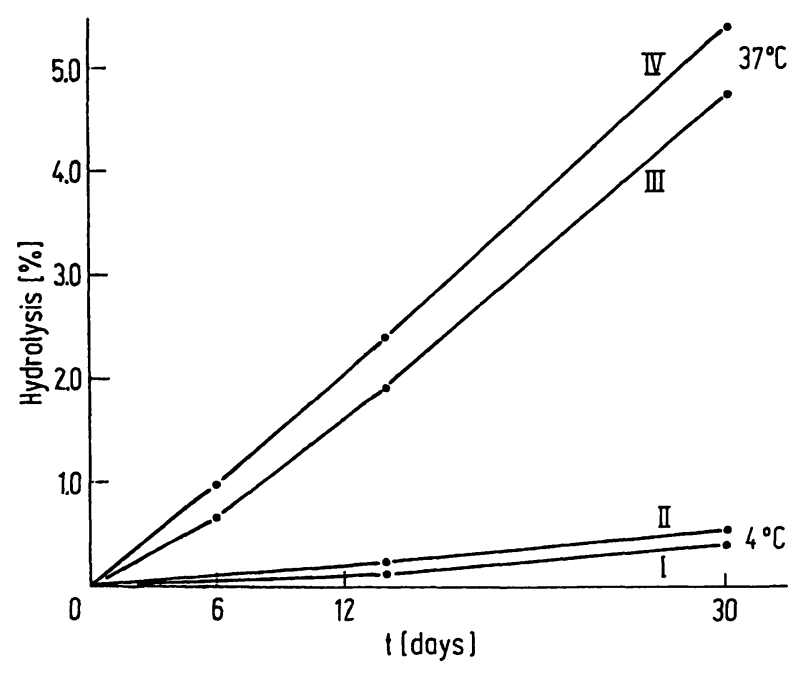

Fig. 2

Spontaneous hydrolysis of substrate as a function of time and temperature. Curves I and III represent the peptidase and curves II and IV the transpeptidase substrate

\section{Stability of the enzyme}

Serum and cerebrospinal fluid, taken under sterile conditions, retain enzyme activity for about $24 \mathrm{hrs}$ at room temperature ( $\max$. loss $3 \%$ ) and for about 8 days at $4^{\circ} \mathrm{C}$. Frozen at $-20^{\circ} \mathrm{C}$ these liquids can be stored for more than one year without significant loss of enzyme activity.

D. Enzyme activity and serum dilution BEER's Law

According to Goldbarg and coworkers (11) enzyme activity is linearly related to the amount of liberated $\alpha$-naphthylamine, up to $6.7 \%$ concentration in the substrate solution. These authors were forced to use correction factors for protein concentration which are difficult to standardize. Nevertheless we could confirm these observations with our technique, which does not require deproteinization. More specifically, we found the quantity of liberated $\alpha$-naphthylamine to be linear with the enzyme activity of the serum up to $66 \mu$ moles/ $1000 \mathrm{~m} / \mathrm{min}$ at $37^{\circ}$, which corresponds to an $8 \%$ hydrolysis of the substrate. Furthermore, the extinction and concentration of $\alpha$-naphthylamine displayed a linear correspondence (fig. 3). The absorption maximum lies at $535 \mathrm{~nm}$ (fig. 4).

\section{E. Substrate concentration and enzymic activity}

GolDBARg and coworkers (11) worked with a substrate containing $2.25 \mu$ moles $\gamma$-glutamyl-anilide per $\mathrm{ml}$. ORLOWsKI and SzEwczuK (7) concluded that the optimal concentration of $\gamma$-glutamyl- $\alpha$-naphthylamide must be higher than $20 \mu$ moles $/ \mathrm{ml}$. Such a concentration cannot be achieved because of the limited solubility of $\gamma$-glutamyl- $\alpha$-naphthylamide. Therefore, these authors worked with a concentration of $10 \mu$ moles $/ \mathrm{m} l$ in the final test solution. By reducing the amount of the serum sample and using a substrate solution with a concentration of $10 \mu$ moles $/ \mathrm{m} l$ 


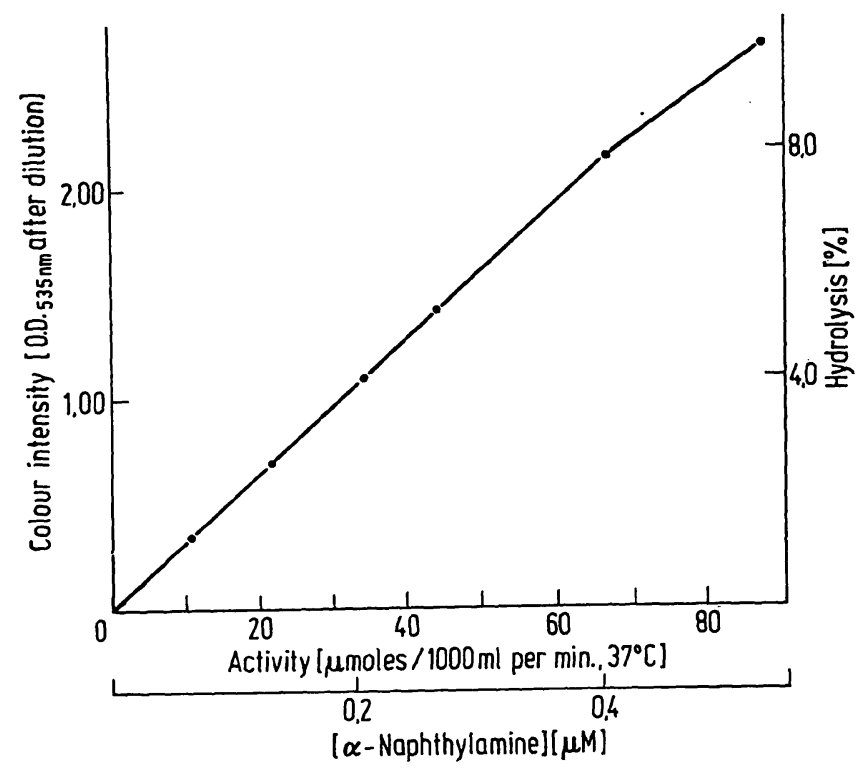

Fig. 3

Relation between the calculated colour intensity expressed as $O$. D after dilution and $\alpha$-naphthylamine concentration, expressed as after dilution and $/ 000 \mathrm{ml} / \mathrm{min}$ at $37^{\circ}$ or as absolute concentration in each test tube.

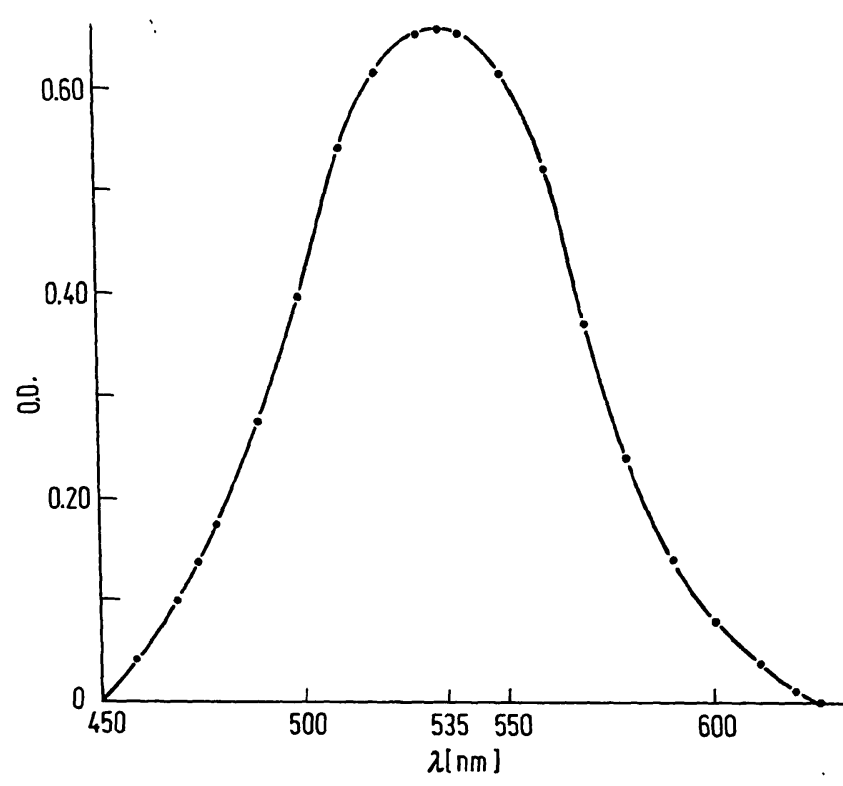

Fig. 4

Absorption spectrum of the diazo dye. Maximum absorption is noted by $535 \mathrm{~nm}$

$\gamma$-glutamyl- $\alpha$-naphthylamide, we obtained a concentration of $8.33 \mu$ moles $\gamma$-glutamyl- $\alpha$-naphthylamide $/ \mathrm{m} l$ in the test solution (fig. 5).

\section{F. Incubation time and enzymic activity}

Working with an homogenate of rat kidney $(0.1 \mathrm{mg} / \mathrm{ml})$, GoLDBARG and coworkers (4) found a linear relation between enzyme activity and incubation time up to $4 \mathrm{hrs}$. The same linear relationship between the extinction (or calculated enzymic activity) and the incubation time, was observed in serum for both hydrolysis and transpeptidation under comparable conditions. Furthermore, we demonstrated a dependency of this linearity on the relative enzyme activity, by incubating a serum with a known activity (15 $\mu$ moles $/ 1000 \mathrm{~m} / \mathrm{min}$ at

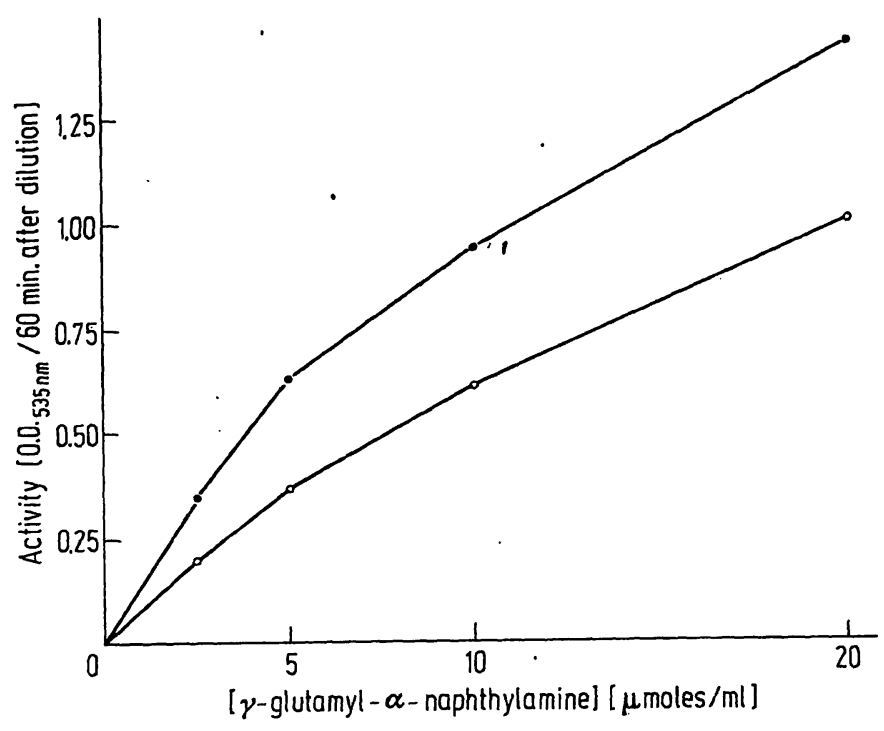

Fig. 5

Effect of the concentration of $\gamma$-glutamyl- $\alpha$-naphthylamide (substrate solution) on the enzyme ( $0-0)$ peptidase and internal transpeptidase, - transpeptidase) activities

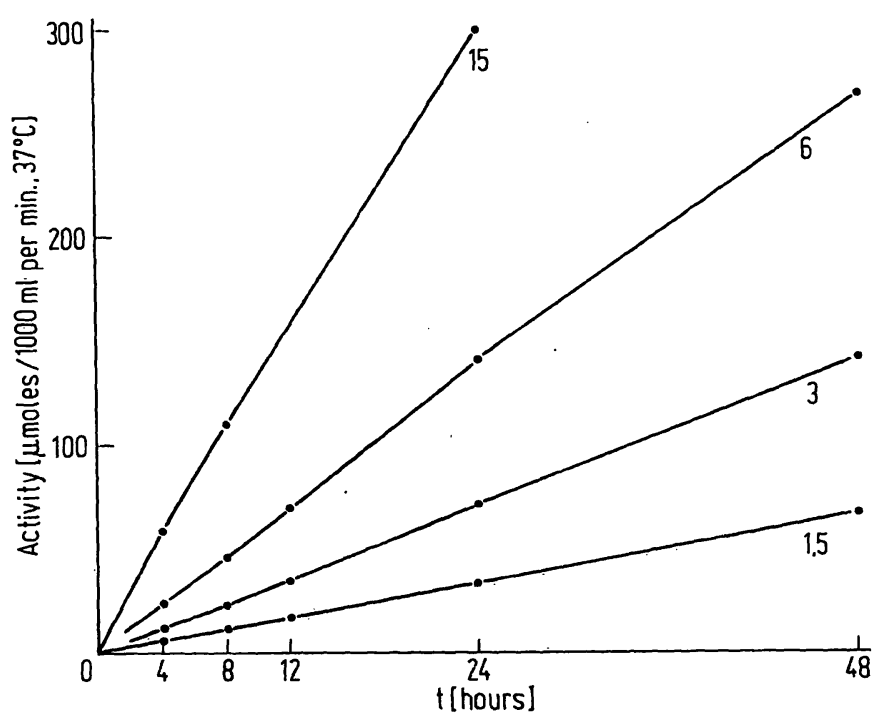

Fig. 6

Effect of incubation time on enzyme activity in serum (expressed as $\mu$ moles $\alpha$-naphthylamine $/ 1000 \mathrm{ml} / \mathrm{min}$ at $37^{\circ}$ ). The numbers on the lines will denote the activity of the incubated serum resp. serum dilution. The relation is linear up to $4 \mathrm{hrs}$ for an activity up to
$15 \mu \mathrm{moles} / 1000 \mathrm{ml} / \mathrm{min}$ at $37^{\circ}$

$37^{\circ}$ ) at different dilutions (fig. 6). This experiment revealed that enzyme activities up to $15 \mu$ moles/ $1000 \mathrm{ml} / \mathrm{min}$ at $37^{\circ}(\gamma$-glutamyl peptidase and $\gamma$-glutamyl transpeptidase) are linear for a periogd of $4 \mathrm{hrs}$. Lower activities retain their linearity for much longer periods of time, up to $48 \mathrm{hrs}$. The observation is in agreement with the curve in figure 3 , and permits

Tab. 1

The effect of different concentrations $(v / v)$ of propylene glycol on the extinction of the test solution. The optimal composition is outlined

\begin{tabular}{lrr|r|r}
\hline Propylene glycol & 0 & 5 & 10 & 15 \\
Methanol & 50 & 45 & 45 & 40 \\
Water & 50 & 50 & 45 & 45 \\
\cline { 2 - 5 } $\begin{array}{l}\text { percent extinction } \\
\text { at 535 nm }\end{array}$ & 60 & 90 & 100 & 98 \\
\hline & & & & \\
\hline
\end{tabular}

Z. klin. Chem. u. klin. Biochem. / 8. Jahrg. 1970/ Heft 6 
Tab. 2

The effect of different concentrations $(v / v)$ of methanol and water on the extinction of the test solution. The optimal cornposition is outlined

\begin{tabular}{|c|c|c|c|c|c|c|c|c|c|c|c|}
\hline $\begin{array}{l}\text { Propylene glycol } \\
\text { Methanol } \\
\text { Water }\end{array}$ & $\begin{array}{r}10 \\
0 \\
90\end{array}$ & $\begin{array}{l}10 \\
10 \\
80\end{array}$ & $\begin{array}{l}10 \\
20 \\
70\end{array}$ & $\begin{array}{l}10 \\
30 \\
60\end{array}$ & $\begin{array}{l}10 \\
40 \\
50\end{array}$ & $\begin{array}{l}10 \\
45 \\
45\end{array}$ & $\begin{array}{l}10 \\
50 \\
40\end{array}$ & $\begin{array}{l}10 \\
60 \\
30\end{array}$ & $\begin{array}{l}10 \\
70 \\
20\end{array}$ & $\begin{array}{l}10 \\
80 \\
10\end{array}$ & $\begin{array}{r}10 \\
90 \\
0\end{array}$ \\
\hline $\begin{array}{l}\text { percent extinction } \\
\text { at } 535 \mathrm{~nm}\end{array}$ & 62 & 70 & 76 & 80 & 94 & 100 & 95 & 94 & 94 & 94 & 94 \\
\hline
\end{tabular}

determination of low hydrolytic and transpeptidase activities by prolongation of the incubation time. For example enzyme activities in cerebrospinal fluid can be measured after an incubation period of $24 \mathrm{hrs}(15,16)$.

\section{G. Dilution fluid and colour intensity}

In order to permit direct colorimetric measurements after incubation without deproteinization and without possible loss of the liberated $\alpha$-naphthylamine, various diluents were evaluated. A mixture of propylene glycol/methanol/water $(10: 45: 45 ; \mathrm{v} / \mathrm{v})$ dilutes the reaction mixture indefinitely without causing turbidity. Of course, the blank must be treated identically. The optimum composition of this mixture is revealed from tables 1 and 2 .

\section{H. The diazo reagent}

The effect of various compositions of the diazo reagent on the colour intensity was investigated, and is shown in tables 3 and 4, where the optimal composition is outlined.

Tab. 3

The effect of different concentrations $(v / v)$ of sodium nitrite on the extinction of the test solution

\begin{tabular}{lcr|rr}
\hline Sodium nitrite 1\% & 0.25 & 0.50 & 1.00 & 2.00 \\
Sulphanilic acid sol. & 5.00 & 5.00 & 5.00 & 5.00 \\
Water & 14.75 & 14.50 & 14.00 & 13.00 \\
\cline { 2 - 5 } & 71 & 100 & 34 & 0 \\
\hline
\end{tabular}

Tab. 4

The effect of different concentrations ( $v / v)$ of sulphanilic acid solution on the extinction of the test solution

\begin{tabular}{|c|c|c|c|c|c|}
\hline $\begin{array}{l}\text { Sodium nitrite } 1 \% \\
\text { Sulphanilic acid sol. } \\
\text { Water }\end{array}$ & $\begin{array}{r}0.50 \\
3.00 \\
16.50\end{array}$ & $\begin{array}{r}0.50 \\
4.00 \\
15.50\end{array}$ & $\begin{array}{r}0.50 \\
4.50 \\
15.00\end{array}$ & $\begin{array}{r}0.50 \\
5.00 \\
14.50\end{array}$ & $\begin{array}{r}0.50 \\
6.00 \\
13.50\end{array}$ \\
\hline $\begin{array}{l}\text { percent extinction } \\
\text { at } 535 \mathrm{~nm}\end{array}$ & 51 & 85 & 89 & 100 & 97 \\
\hline
\end{tabular}

I. Sensitivity and reproducibility of the method When $0.1 \mu \mathrm{M} \quad \alpha$-naphthylamine was diazotized according to Griess (12) or after. Bratton-MARShaLL, as described by ORLOWSKI and SzEwCzUK (7) with the same end volume $(6.0 \mathrm{ml})$, the extinction at $535 \mathrm{~nm}$ was 0.56 and 0.48 respectively. Although the direct diazotation after GrIESs is more sensitive than that after BratTon-MARSHALL, the difference is not significant. The reproducibility of both diazotation methods is good; the maximal deviation with the GrIEss method lies at O.D. $=0.01$ and with the Bratton-MARŚhaLL procedure by $O . D .=0.02$. Because of the greater number of manipulations involved in the latter technique, we have adopted the former for our procedure.

\section{Clinical Results}

\section{A. Normal values}

Using this method and the two substrates described above, the following values for serum were obtained in a normal population of:

\section{Adults (2 487 cases)}

- peptidase activity and internal transpeptidation:

mean value: $4.5 \mu$ moles $/ 1000 \mathrm{~m} / / \mathrm{min}$ at $37^{\circ}$; S. D. $\pm 1.52$

(range from 1.5 to $7.5 \mu \mathrm{moles} / 1000 \mathrm{~m} / / \mathrm{min}$ at $37^{\circ}$ ).

- transpeptidase activity:

mean value: $6.3 \mu$ moles $/ 1000 \mathrm{~m} / / \mathrm{min}$ at $37^{\circ}$; S. D. $\pm 2.11$

(range from 2.1 to $10.5 \mu$ moles $/ 1000 \mathrm{~m} / / \mathrm{min}$ at $37^{\circ}$ ).

Cbildren up to age 6 years (432 cases)

- peptidase activity and internal transpeptidation:

mean value: $2.5 \mu$ moles $/ 1000 \mathrm{~m} / \mathrm{min}$ at $37^{\circ}$; S. D. $\pm 0.75$

(range from 1.0 to $4.0 \mu$ moles $/ 1000 \mathrm{~m} / / \mathrm{min}$ at $37^{\circ}$ ).

-transpeptidation activity:

mean value: $3.5 \mu$ moles $/ 1000 \mathrm{~m} / / \mathrm{min}$ at $37^{\circ} ; \mathrm{S} . \mathrm{D}$. $\pm 1.05$

(range from 1.5 to $5.7 \mu \mathrm{moles} / 1000 \mathrm{~m} / / \mathrm{min}$ at $37^{\circ}$ ).

\section{B. Results}

High $\gamma$-glutamyl transpeptidase activities (with or without added glycyl-glycine) were found in cases of cirrhosis, in obstructive jaundice (of different origin), intrahepatic damage of the bile canniculi or atresia of the external bile ducts, as well in the extrahepatic obstruction by cholelithiasis. The serum enzyme activity becomes higher as the occlusion becomes more complete. Surgical intervention in cases of cholelithiasis normalizes the $\boldsymbol{\gamma}$-glutamyl transpeptidase activity in a few days or weeks.

In patients with lithiasis of the bile bladder, without obstruction of the bile ducts, the serum enzyme activity was mostly normal or unspecifically increased (up to $20 \mu$ moles $/ 1000 \mathrm{~m} / / \mathrm{min} / 37^{\circ}$ ). In cases, such as cholangitis, were any narrowing of the bile ducts by mucus or by cells can be suspected, moderately increased serum $\gamma$-glutamyl transpeptidase activities were found. All patients with viral, drug or chronic hepatitis, had a increased $\boldsymbol{\gamma}$-glutamyl transpeptidase activity, ranging from 15.1 to $45.1 \mu$ moles $/ 1000 \mathrm{~m} / / \mathrm{min} \cdot 37^{\circ}$.

There is an overlap in the activity from one disease to another and table 5 gives the range of values of the 
Tab. 5

Serum $\gamma$-glutamyl transpeptidase activity expressed as $\mu$ moles/ $1000 \mathrm{~m} / \mathrm{m}_{\mathrm{min}}$ at $37^{\circ}$, without added glycylglycine in some diseases $\begin{array}{llll}\begin{array}{c}\text { Number } \\ \text { of } \\ \text { Patients }\end{array} & \begin{array}{c}\text { Ranging } \\ \text { from - to }\end{array} & \begin{array}{c}\text { Mean } \\ \text { Values }\end{array} & \begin{array}{c}\text { S. D. } \\ \pm\end{array}\end{array}$

\begin{tabular}{|c|c|c|c|c|}
\hline $\begin{array}{l}\text { Anictcric patients } \\
\text { Pleuresia (viral or } \\
\text { tubercular) } \\
\text { Liver metastases } \\
\text { Pancreatitis } \\
\text { Diabetes } \\
\text { Renal syndrome } \\
\text { Neurological diseases } \\
\text { Myopathias }\end{array}$ & $\begin{array}{r}35 \\
59 \\
3 \\
54 \\
117 \\
117 \\
64\end{array}$ & $\begin{array}{l}16.2-37.4 \\
40.0-250 \\
\text { resp. } 10.4-13.9 \\
6.7=19.5 \\
2.1-9.9 \\
1.5-7.5 \\
1.4-2.8\end{array}$ & $\begin{array}{l}26 \\
145 \\
9 \text { and } 19.8 \\
13.1 \\
6.0 \\
4.5 \\
2.1\end{array}$ & $\begin{array}{l}5.3 \\
52.5 \\
3.2 \\
1.95 \\
1.5 \\
0.35\end{array}$ \\
\hline \multicolumn{5}{|l|}{ Icteric patients } \\
\hline \multirow{2}{*}{$\begin{array}{l}\text { Viral hepatitis } \\
\text { Drug hepatitis } \\
\text { Chronic hepatitis } \\
\text { Cirrhosis } \\
\text { Obstructive jaundice } \\
\text { Intrahepatic cholestasis }\end{array}$} & $\left.\begin{array}{r}93 \\
5\end{array}\right\}$ & $15.1-41.9$ & 28.5 & 6.7 \\
\hline & $\begin{array}{r}19 \\
48 \\
37 \\
5\end{array}$ & \multirow{2}{*}{$\begin{array}{l}17.9-45.1 \\
10.0-70.4 \\
40.3-104.7 \\
\text { resp. } 14 \text { and } 16.8 \\
\text { resp. } 112-118 \\
37.2-175\end{array}$} & $\begin{array}{l}31.5 \\
40.2 \\
72.5 \\
\text { and } 150\end{array}$ & $\begin{array}{r}6.8 \\
15.1 \\
16.1\end{array}$ \\
\hline Hepatic neoplasms & 23 & & & 34.5 \\
\hline
\end{tabular}

$\gamma$-glutamyl transpeptidase activities in some diseases. The $\gamma$-glutamyl transpeptidase activity was also determined in the cerebrospinal fluid $(15,16)$. Evidence was found that an increased enzymic activity in the cerebrospinal fluid was independent of the total protein content, the number of the cells or the clinical symtomology, but it was subsequent to brain damage.

When the serum enzyme activity, measured without added glycyl-glycine ( $\gamma$-glutamyl peptidase and internal transpeptidation) was called $100 \%$, the enzyme activity in the presence of $100 \mathrm{mg}$ added glycyl-glycine $(\gamma$ glutamyl transpeptidase) showed an average of $140 \%$. That means that the addition of glycylglycine, caused an average $40 \%$ activation of the total activity. An exception was found in the serum of 4 patients with myopathia, for which no activation by glycyl-glycine could be detected. In one individual the activation by glycylglycine was not constant but changed with time. The highest percentage activation was found at the beginning of any acute process involving the liver, such as a viral or a drug hepatitis, where an activation of up to $400 \%$ was noted in certain cases.

In cases, which showed no spectacular changes of the $\gamma$-glutamyl transpeptidase activity, e. g., in cases of cirrhosis, there was also no high degree of activation by glycylglycine. In other cases, such as in liver cancer or in obstructive jaundice, in which the $\gamma$-glutamyl transpeptidase reached a maximum activity in the course of time, the activation maximum by glycylglycine coincides with the peptidase activity maximum.

Analogous observations were made for the cerebrospinal fluid, where the activation by glycylglycine, is highest in cases of acute cell damage.

\section{Discussion}

The highest serum $\boldsymbol{\gamma}$-glutamyl transpeptidase activity was found in anicteric patients, with liver metastases, followed by icteric patients with hepatic neoplasms or obstructive jaundice of diverse origin. The more complete the obstruction, the higher was the serum $\gamma$-glutamyl transpeptidase activity. In our experience, the increase of the serum $\gamma$-glutamyl transpeptidase activity is a specific and very sensitive index of any cholestasis.

Liver damage and obstruction give an acceptable explanation for the observations made with the substrate without added acceptor. However, it does not explain the differences noted, in the activation in the presence of a constant quantity of added glycylglycine. On the other hand, there are the observations of Drmov and KulHaneK (19), who noted a relative activity of $165 \%$ for normal sera and $138 \%$ for pathological sera with the $\alpha$-naphthylamine method in the presence of glycylglycine in comparison to its absence. These authors explain these statistical differences by the "heterogeneous form of the enzyme, from which some may be activated more than others. Further the substrate itself may be split more readily by one iso-enzyme than by others. The differences in pathological sera may be caused by the different iso-enzyme patterns of the individual organs and the final relation between iso-enzymes would then affect the results. Besides, there is also the possibility that the activity of heterogeneous forms of $\gamma$-glutamyl transpeptidase may be, in different ways, influenced by ethio-pathogenic factors in various diseases."

SzCZEKLIK and coworkers (9) supposes "a higher rate of synthesis of the enzyme as an adaptive response to the pathological changes in these diseases and an overflow of the enzyme into the blood stream."

Without rejecting any of these hypotheses, proposed by others, we would nevertheless look for an explanation in the observations made by Szewczuk (20). This author demonstrated the presence, in both the liver and the kidney, of a microsomal (insoluble) enzyme, which is related to the soluble (free) form, which occurs in serum.

They also could present evidence that, particularly in the liver, the microsomal enzyme may be transformed into the soluble state during incubation of liver homogenates.

In view of these observations, there is good evidence that the increased activation in the presence of glycylglycine, during the acute phase of an hepatitis, is an. increased (enzymic?) conversion of the microsomal enzyme to the soluble form and that the transpeptidation activity increases more readily than the peptidase.

With this hypothesis it is possible to explain the increase of the serum $\gamma$-glutamyl transpeptidase activity as the result of necrosis of the cells and the solublisation of the microsomal enzyme(s) on the one hand, and the intra-or extra-hepatic obstruction on the other.

\section{Acknowledgements}

I wish to express my sincere gratitude to Professor W. ZEMAN, Dept. of Pathology and Neurology of the University of Indianapolis, for his help in the preparation of the manuscript and for the benefit of his valuable advice.

I am indebted to Dr. L. van BogarRT, Director of the Institute Bunge, for his help and encouragement. 


\section{References}

1. HANES, C. S., F. J. R. Hird and F. A. Isherwood, Nature (London) 166, 288 (1950). - 2. HANEs, C. S., F. J. R. HrRD and F. A. Isherwood, J. Biochemistry (Tokyo) 51, 25 (1952). 3. Rever, J. P. and E. G. Ball, J. biol. Chemistry 234, 577 (1959). 4. Goldbarg, J. A., O. M. Friedman, E. P. Peneda, E. E. Smith, R. Chatterju, E. H. Stenn and A. M. Rutenburg, Arch. Biochem. Biophysics 91, 61 (1960). - 5. OrLowskr, M. and A. SzzwCzUK, Clin. chim. Acta, Amsterdam 6, 430 (1961). - 6. Szewczux, A. and M. Orfowski, Clin. chim. Acta, Amsterdam 5, 680 (1960). 7. Orlowski, M. and A. Szewczur, Clin. chim. Acta, Amsterdam 7, 755 (1962). - 8. Albert, Z., M. Orlowski and A. SzewCzuK, Nature (London) 191, 767 (1961). - 9. SzCzEkLIK, E., M. OrLowskr and A. SzewCzuK, Gastroenterology, Baltimore 41, 353 (1961). - 10. GlenNer, G. G. and J. E. FolK, Na- ture (London) 192, 338 (1961). - 11. Goldbarg, J. A., E. P. Pineda, E. E. Smith, O. M. Friedman and A. M. Rutenburg, Gastroenterology, Baltimore 44, 127 (1963). - 12. Griess, P., Ber. dtsch. chem. Ges. 12, 426 (1879). - 13. KuLfaneK, V. and D. M. Drmov, Clin. chim. Acta, Amsterdam 14, 619 (1966). 14. Dimov, D. M. and V. Kulhanek, Clin. chim. Acta, Amsterdam 16, 271 (1967). - 15. Swinnen, J., Clin. chim. Acta, Amsterdam 17, 255 (1967). - 16. SwinNen, J. and TH. DE BARSY, Acta neurol. psychiatri Belg. 66, 939 (1966). - 17. Swinnen, J., in press. - 18. SzewczUK, A. and T. BARANowskI, Biochem. $Z$. 338, 317 (1963). - 19. Drmov, D. M. and V. Kulhanek, Clin. Chim. Acta, Amsterdam 16, 271 (1967). - 20. Szewczuk, A., Clin. Chim. Acta, Amsterdam 16, 608 (1966).

J. Swinnen

Apoteker-Klinisch Bioloog.

J. de Sadelerslaan, 9

B-2520, Edegem (Belgium) 